\title{
流下方向に密度の変化する水際樹木群を有する 複断面開水路乱流の発達過程 GROWTH OF TURBULENT FLOW IN A COMPOUND OPEN CHANNEL WHERE VEGETATION DENSITY CHANGES IN THE DOWNSTREAM DIRECTION
}

\author{
駒井克昭 ${ }^{1} \cdot$ 福岡捷二 ${ }^{2} \cdot$ 渡辺明英 $^{3} \cdot$ 大本泰久 4 \\ Katsuaki KOMAI, Shoji FUKUOKA, Akihide WATANABE, and Yasuhisa OMOTO \\ 1学生員 広島大学大学院 工学研究科 (テ739-8527 東広島市鏡山1-4-1) \\ 2フェロー会員 Ph.D. 工博 広島大学教授 工学部第 4 類（建設系）（同 上） \\ 3 正会員 工博 広島大学助教授 工学部第 4 類 (建設系) ( 同 上 ) \\ 4正会員 日本工営株式会社（广980-0021 仙台市青葉区中央二丁目2番6号）
}

\begin{abstract}
A turbulent velocity field was measured in a vegetated compound open channel flow where vegetation density changed abruptly from low to high and high to low in the downstream direction. The changing process of mean velocity, secondary currents and Reynolds stress fields were explained with three dimensional mixing structure caused by large horizontal eddies. As a result, three dimensional structure of turbulent flow, and relation between mean velocity field and turbulent structure were clarified experimentally in an open channel flow with abrupt change in the vegetation density in the downstream direction.
\end{abstract}

Key Words : compound open channel, vegetation, large horizontal eddy, Reynolds stress secondary current

\section{1. 序論}

河道の水際には柳などの植生が育ちやすい. 複断面河 道では低水路河岸に連続的に繁茂した樹木群が多くみら れる. 樹木群の連続性と広がりは生態学的に重要な役割 を果たすと認められているが，植生の繁茂は流水抵抗を もたらし，河道の洪水流下能力を低下させる. したがっ て, 河川の管理や洪水対策, 環境保全のためには水際樹 木群のある複断面河道の流れ特性を十分に把握し, それ を反映することが重要である.

低水路河岸に樹木群が繁茂している複断面河道では, 樹木群領域での流速が主流域に比べて非常に遅く, 横断 方向に大きな速度勾配を生じる. このため周期的な水平 混合を伴った強い大規模平面渦が発生し, 流水抵抗が大 きくなる1). 福岡・渡辺ら ${ }^{2)}$ は，この流れ場の平面構造を 明らかにしている. また，実河川では河道内の樹木群は 多様な繁茂形態を有しており，それについての検討も必 要である. 辻本・北村ら ${ }^{3)}$, 冨永・長尾ら ${ }^{4)}$ は樹木群密生 度や樹木群の配置が流れ場に及ぼす影響を検討している.

樹木群のある複断面河道の解析については, 福岡・藤
田ら ${ }^{5)}$ の境界混合係数を用いた準 2 次元解析法が実用化 されている. 平面 2 次元解析については灘岡・八林)， 福岡・渡辺ら ${ }^{2)}$ の研究があり, 福岡・渡辺ら ${ }^{7)}$ は利根川の 実洪水においても樹木群による大規模平面渦と流れ場の 平面流況の再現ができることを示している. しかし，樹 木群のある河道における大規模平面渦と平均流速場を 3 次元的に精度良く表現できる数值モデルは未だ開発され ていない. 著者ら ${ }^{8)}$ はスペクトル法を用いた 3 次元数值 モデルを用いて, 樹木群のある直線複断面流れの解析を 試みているが実験結果を説明できる段階には至っていな ).

このように，樹木群を有する複断面河道の平面的な流 れ場については実験的，解析的に明らかにされているが， 流れ場の3 次元構造は今なお十分明らかになっていない. また, 実河川で一般的な河岸沿い流下方向に樹木群の繁 茂条件が変化する場合について流れの構造の変化過程の 解明は不十分である. このように, 樹木群のある流れ場 の3 次元構造については今なお実験的にも解析的にも未 解明な部分は多く残されている.

本論文では，低水路河岸に樹木群が繁茂する複断面河 道流れの 3 次元構造とその変化過程を明らかにするため, 


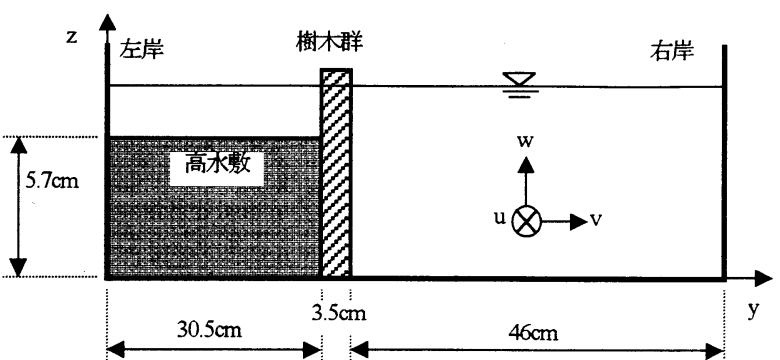

図-1 実験水路の断面図

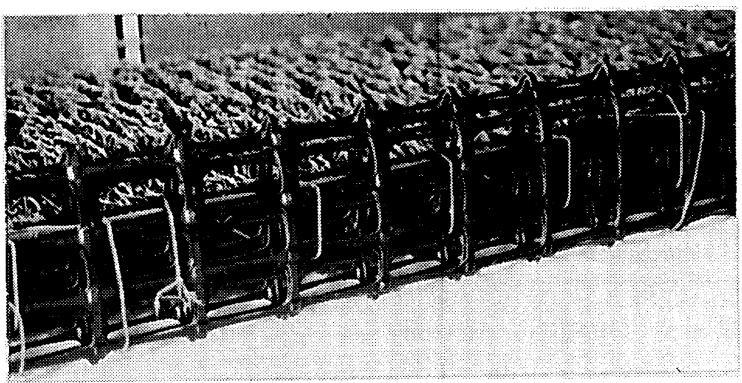

写真-1 粗な樹木群模型 $(\mathrm{K}=1.74 \mathrm{~m} / \mathrm{s})$

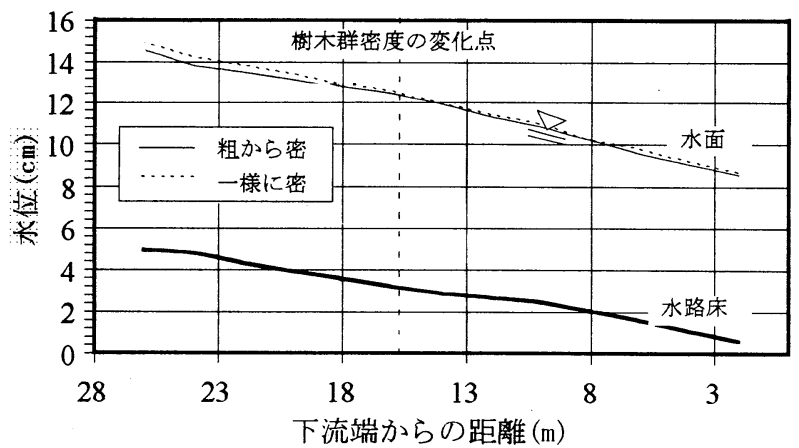

図-3 絎断水位

樹木群密度が流下方向に「粗から密」に変化する場合と 「密から粗」に変化する場合の 2 ケースについて実験的 検討を行った. 本文ではまず，「粗から密」の場合の流 れ場の 3 次元構造とその変化過程について述へ，つぎに

「密から粗」の場合の変化過程について前者との相違点 を検討する.

\section{2. 実験方法}

実験水路の断面図を図-1，平面図を図-2に示寸，全長 $28 \mathrm{~m}$ ，全幅 $0.8 \mathrm{~m}$ ，低水路幅 $0.5 \mathrm{~m}$ ，高水敷幅 $0.3 \mathrm{~m}$ ，高水敷 高さ $5.7 \mathrm{~cm}$ の片側複断面の直線水路である. 水路勾配は 1/500である．樹木群模型は幅 $3.5 \mathrm{~cm}$ で，低水路河岸に縦 断的に連続して配置している.

実験は，樹木群密度が流下方向に粗から密に変化する 場合 (case1) と密から粗に変化する場合 (case2)の 2 ケー スを行った。樹木群密度は 2 ケースとも上流端から 12.2mの断面で変化している. 実験に用いた樹木群模型 を写真-1, 2に示す．異なる 2 種類の樹木群模型の透過性

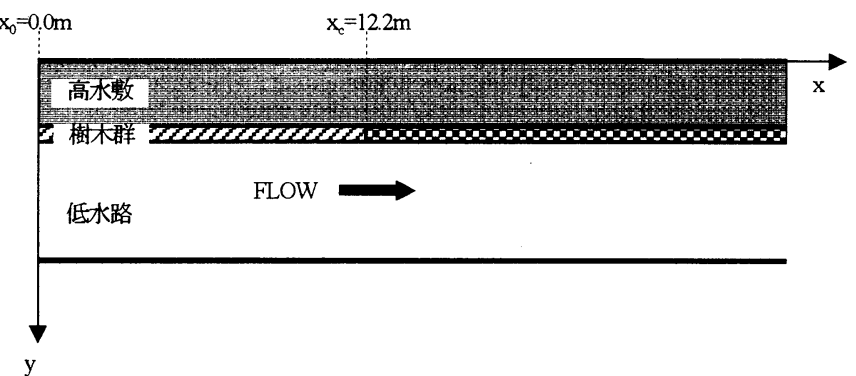

図-2 実験水路の平面図

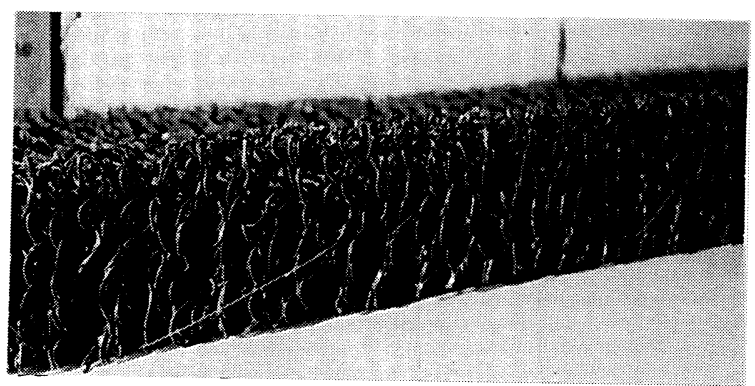

写真-2 密な樹木群模型 $(\mathrm{K}=0.45 \mathrm{~m} / \mathrm{s})$

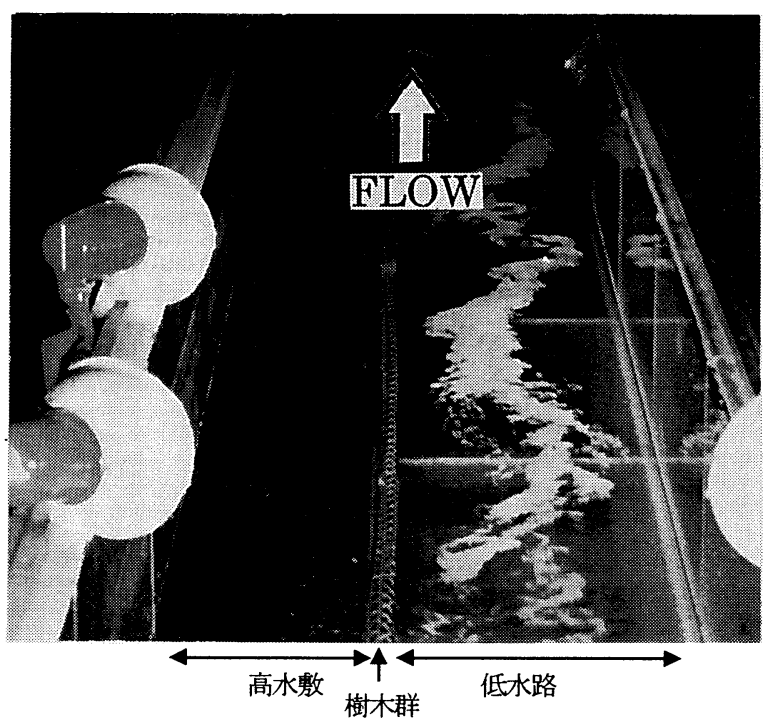

写真-3 流れの可視化の様子

は，透過係数Kで表すことができる．透過係数Kは等流 状態において $v=K i_{e}^{1 / 2}$ で定義され, $v$ : 樹木群内の流速, $i_{e}$ : エネルギー勾配である。粗な樹木群模型では $\mathrm{K}$ $=1.74 \mathrm{~m} / \mathrm{s}$, 密な樹木群模型では $\mathrm{K}=0.45 \mathrm{~m} / \mathrm{s}$ である.

実験は流量を $23.01 / \mathrm{s}$ し，下流端から $2.0 \mathrm{~m}$ での水深 は7. $8 \mathrm{~cm}$ に保たれた．以上の条件で水深は9. $2 \sim 8.2 \mathrm{~cm}$ 程 度であり, 水路の全区間において樹木群模型は水没しな い状態に保たれている.

実験では，LDV（レーザー流速計）を用いてサンプリ ング周波数 $100 \mathrm{~Hz}$ で 3 次元流速変動を測定した. また, 二次流は L 型電磁流速計を用いてサンプリング周波数 $20 \mathrm{~Hz}$ で測定した. 水位変動は容量式波高計を用いてサン プリング周波数 $30 \mathrm{~Hz}$ で測定した. 


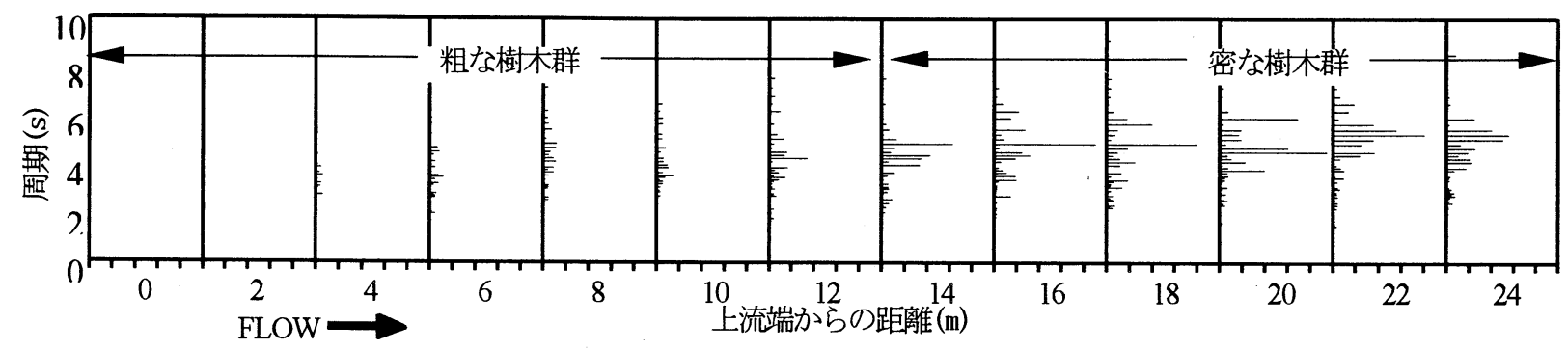

図-4 水位変動スペクトルの縦断変化

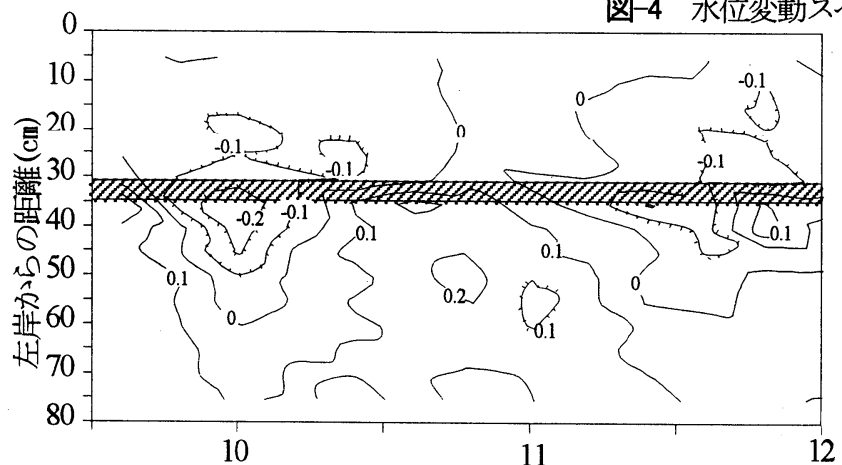

コンター単位 : cm 上流端からの距離 $(\mathrm{m})$

(a) 粗な樹木群領域

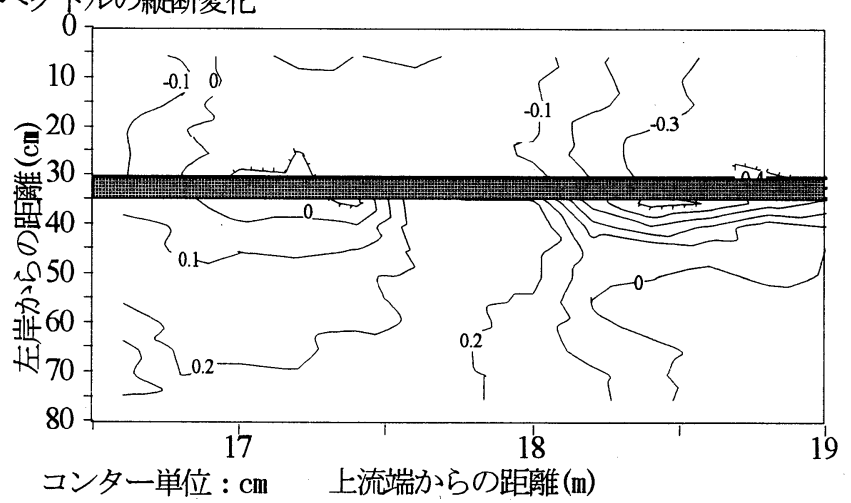

図-5 平面渦の水面コンター

(b) 密な樹木群領域

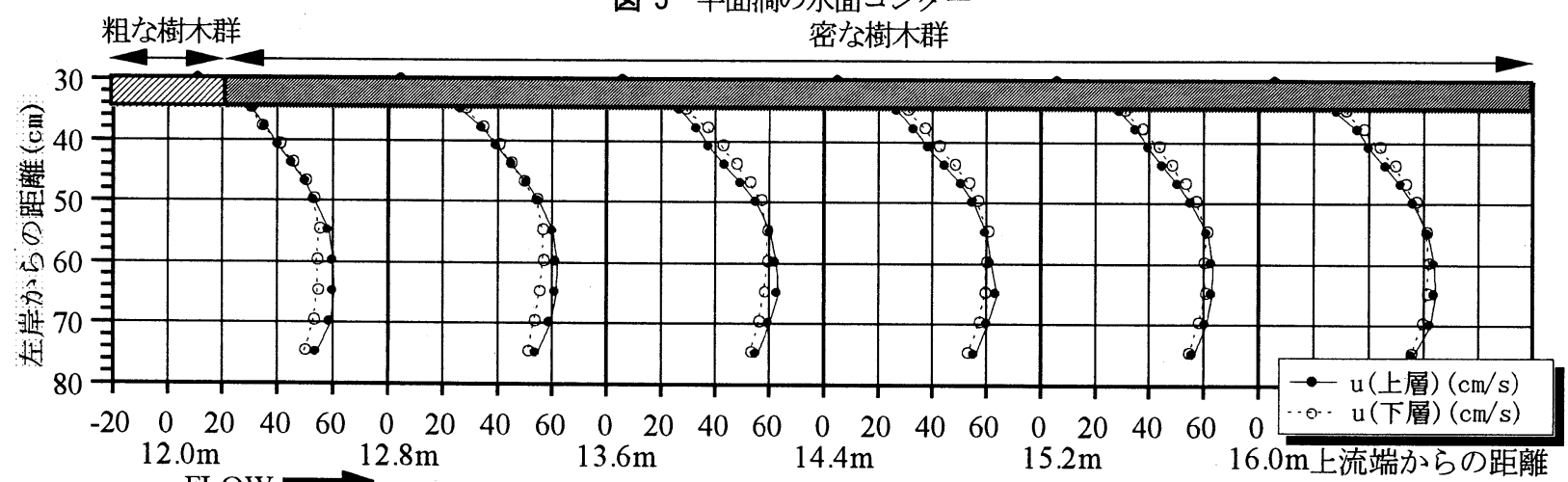

図-6 平均流速分布の檤断変化（低水路のみ）

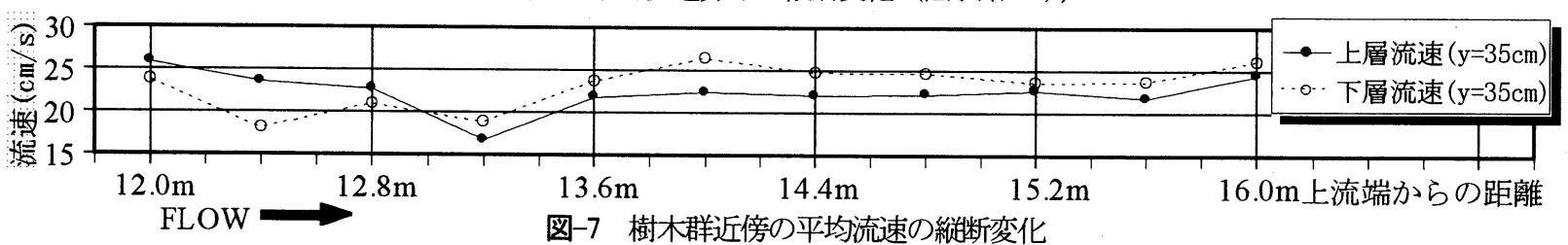

\section{3. 実験結果}

\section{（1）粗から密に変化する場合の変化過程 (case1)}

実験での縦断水位を図-3に示す．比較のために，密な 樹木群を縦断的に一様に設置した実験ケースの值もプ ロットしている。この結果から，上流部の粗な樹木群領 域では密なケースに比べて水位が低く，粗な樹木群領域 は密な樹木群領域に比して流水抵抗が小さいことが分か る.

低水路河岸に樹木群のある直線的な複断面河道では流 れ場が周期的に変動する大規模平面渦が発生する12)3).

写真-3は実験水路にアルミ粉を流したときの写真である. 平面渦により流れが蛇行している様子が可視化されてい る.このような大規模平面渦による水位変動のシグナル
をFFTによりスペクトル解析して求めた水位変動スペク トルの縦断変化を図-4に示す. 図-4では上流の粗な樹木 群領域で弱いスペクトルのピークがみられ，さらに樹木 群密度が粗から密に変化する断面（上流端から12.2m）

より下流において徐々に5sec〜 6sec周期のエネルギース ペクトルが卓越していく様子がとらえられている. この ことより，密な樹木群領域では強い平面渦が発生し，流 れ場の変動が大きくなることが分かる．また上流部の粗 な樹木群領域で発生した弱い平面渦は，樹木群密度が変 化してもすぐには変化せず，徐々に強い平面渦に遷移し ていくといえる.

粗な樹木群領域（上流端から9.5m-12.0m） と密な樹木 群領域（上流端から16.5m-19.0m）の2 区間において波 高計を 2 台用いた水位恋動の条件付きサンプリングを行 い，条件付き抽出アンサンブル平均法により得られた平 

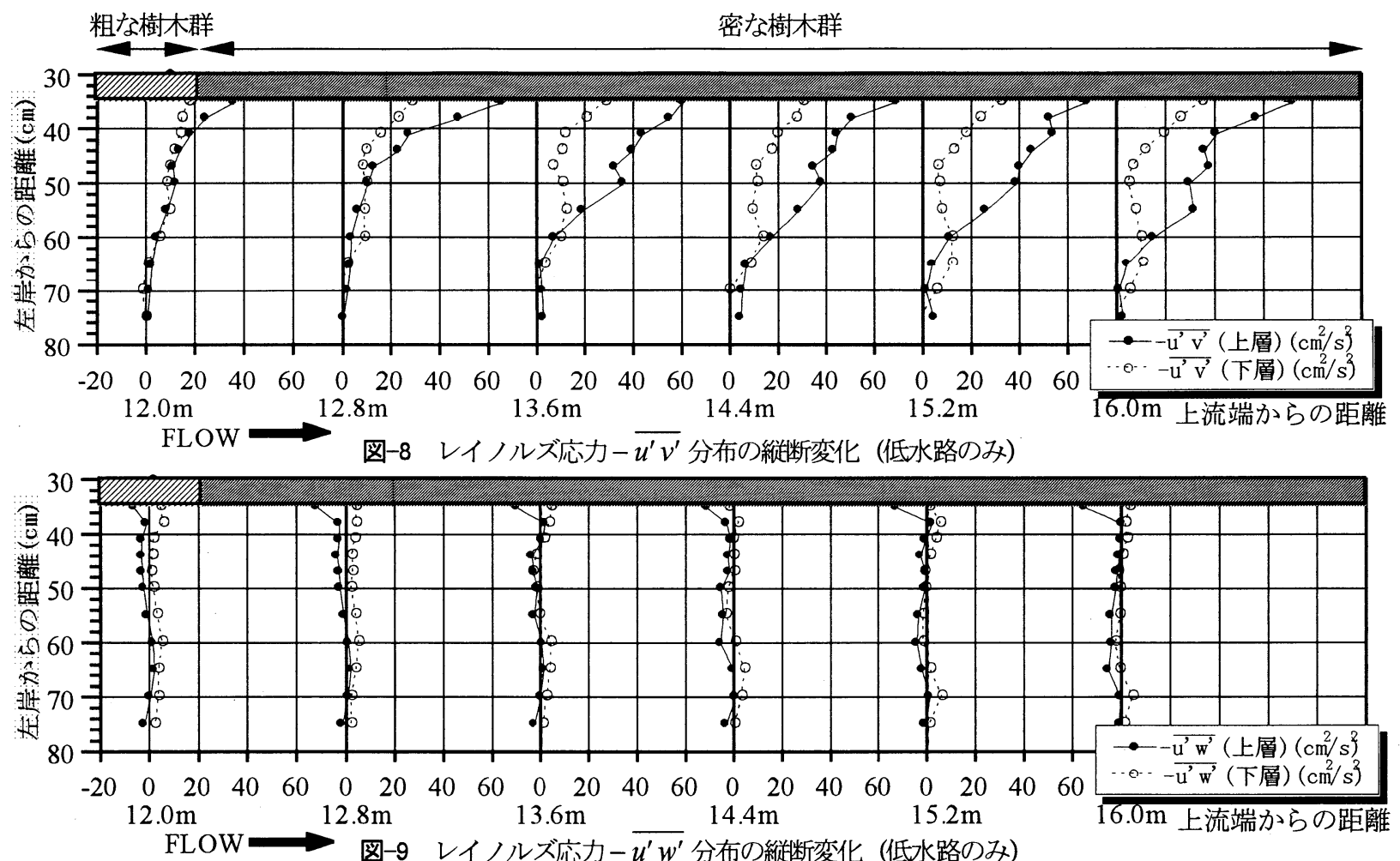

面渦の水面コンターを図-5に示す。粗な樹木群領域と比 較して密な樹木群領域では平面渦による水面変動が高水 敷にまで広がり，樹木群付近には大きな水面勾配が発生 している.

図一6は低水路内の平均流速 $u$, 図-7は樹木群近傍の平 均流速の縦断変化を示す．図-8,9はそれぞれレイノルズ 応力 $-\overline{u^{\prime} v^{\prime}},-\overline{u^{\prime} w^{\prime}}$ の横断分布の維断的な変化を示す. 流れ場の特性は高水敷高さの上層と下層で異なるため, ここでは上層と下層で分けて鉛直平均した值を用いてい る.

図一の平均流速分布では, 各断面ともに樹木群付近の 流速が小さく，樹木群の抵抗が周辺の流れを大きく減速 している. 特に下流部の密な樹木群領域では，下層の流 れが上層より速くなっていることが特徵的である.

しかし，そのような流速分布は樹木群密度の変化直後 にはみられず，樹木群密度の変化断面から1.6m下流（上 流端から13.6m）より現れてくる. 特に樹木群近傍の平 均流速は樹木群密度の変化直後で大きく減速されている ことが図-7から分かる.これは図-8の12.8mの断面でレ イノルズ応力ー $\overline{u^{\prime} v^{\prime}}$ が増大していることに対応する. 減 速された平均流速は2mほど流下した14.0mの断面でほぼ 回復するが，樹木群密度の変化前後で上層と下層の流速 の速さ関係は逆転しており，流れ場の鉛直構造が変化し たことが分かる．これは平面渦による水平混合が上層で 発详しやすく，下層では発達し得ないため，图-8のよう に上層において特に大きなレイノルズ応力 $\overline{u^{\prime} v^{\prime}}$ が生じ るためである.

図-9に示すレイノルズ応力 $-\overline{u^{\prime} w^{\prime}}$ 分布では，樹木群 近傍において負の $-\overline{u^{\prime} w^{\prime}}$ が発生している. これは上層 での水平混合により水面付近が減速された際，鉛直方向

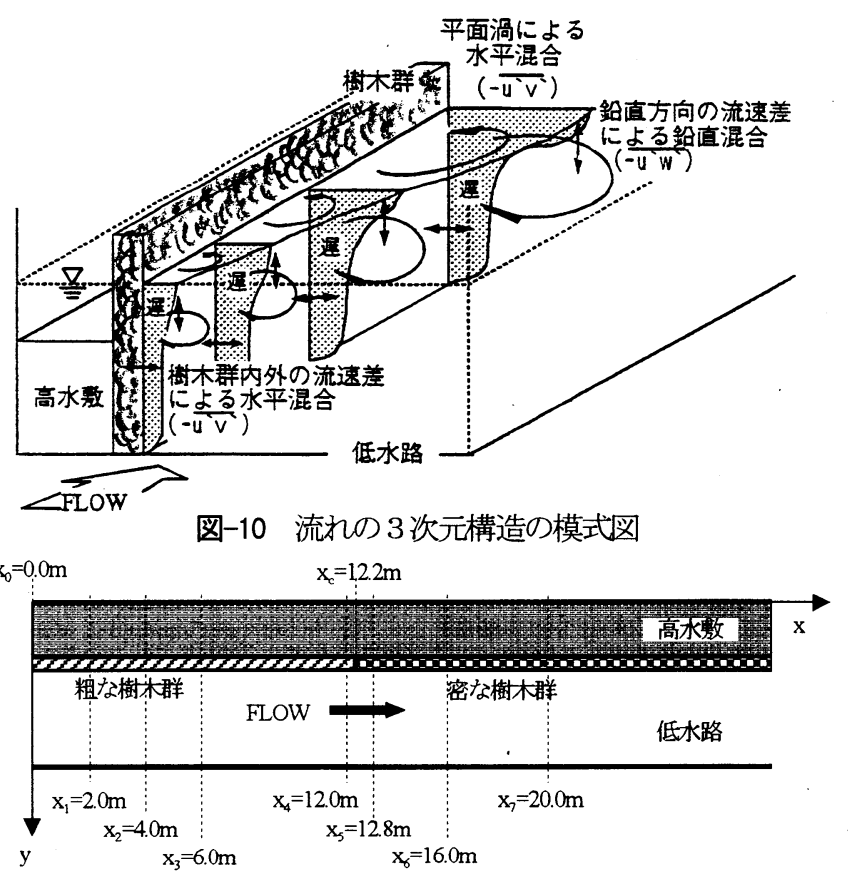

図-11 二次流の測定断面

に流速差が発生し，それに伴い運動量が鉛直方向に輸送 されることを示している. 密な樹木群領域では, 樹木群 近傍のみならず低水路中央付近にも負の $-\overline{u^{\prime} w^{\prime}}$ がみら れ，平面渦の規模の増大により鉛直混合が活発になるこ とを裏付けている。

以上より，樹木群密度が流下方向に粗から密に変化す る場合, 樹木群境界に生じるレイノルズ応力ー $\overline{u^{\prime} v^{\prime}}$ は増 大するが平均流速分布はすぐに変化せず，徐々に樹木群 密度に応じた新たな平均流速分布へと遷移していく.こ の様子を図-10に模式図として表す。 


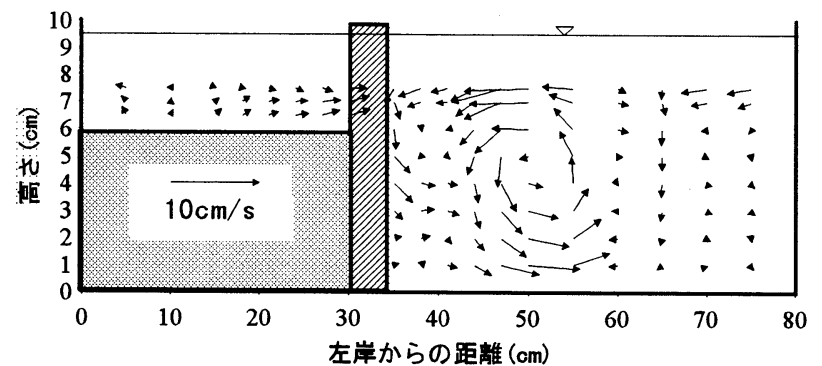

図-12 二次流ベクトル $\left(\mathrm{x}_{1}=2.0 \mathrm{~m}\right)$

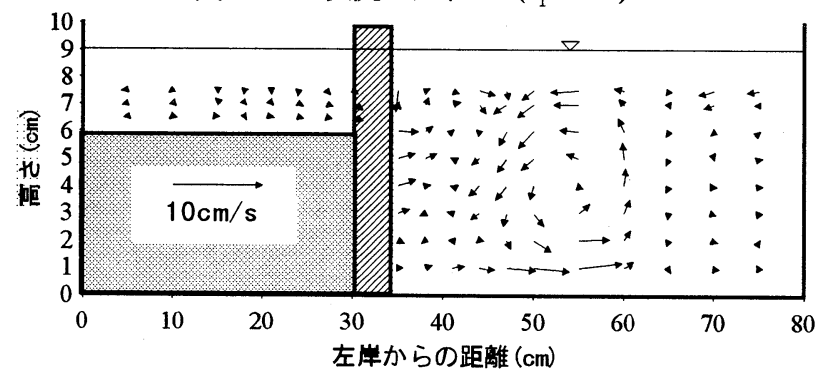

図-13 二次流ベクトル $\left(\mathrm{x}_{2}=4.0 \mathrm{~m}\right)$

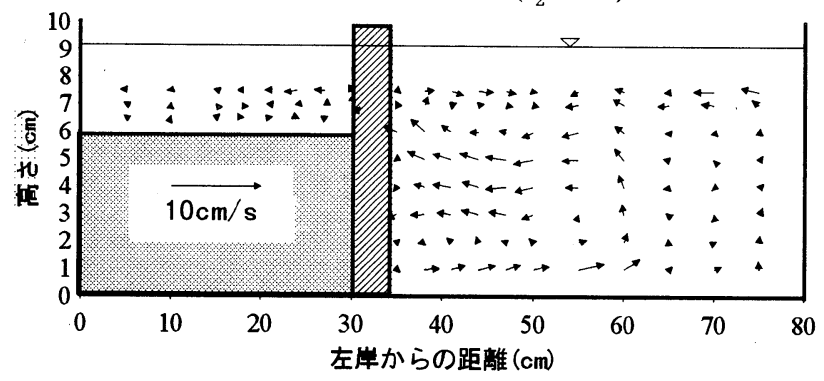

図-14 二次流ベクトル $\left(\mathrm{x}_{3}=6.0 \mathrm{~m}\right)$

次にcase1の二次流の縦断変化を述べる．図-11に二次 流の測定断面を示した.

まず，上流端に最も近い $\mathrm{x}_{1}=2.0 \mathrm{~m}$ （図-12）では，高水 敷と低水路の粗度の違いによる流量配分が未調整なため, 高水敷から低水路八の流入が起こる，それとともに，流 入部の覮乱と樹木群による急激な抵抗により強い反時計 回りの二次流セルが発生している。この断面では水位変 動スペクトル（図-4）を見れば分かるように周期的な変 動は見られず，平面渦は存在しない.

次の断面 $\mathrm{x}_{2}=4.0 \mathrm{~m}$ （図-13）では, 樹木群周辺の水面付 近で二次流セルが弱められている.

さらに流下した $\mathrm{x}_{3}=6.0 \mathrm{~m}$ （図-14）の断面では, 左岸方 向への流れとそれを上下から挟むように，右岸方向への 弱い流れが水面付近と底面付近に発生している。これら の流れは，高水敷高さより上層では時計回り，下層では 反時計回りの 2 つ横長な二次流セルを構成している. この断面では，水位変動スペクトル（図-4）は明確にな りつつあり，平面渦は発達段階にある.

次に, 粗な樹木群領域における最下流部 $\mathrm{x}_{4}=12.0 \mathrm{~m}$ （図 -15）では，上述の 2 つの次流セルに加え，低水路右 岸寄りに二次流セルが発生している.この断面では，弱 い変動ながらも粗な樹木群領域において十分発達した平 面渦が現れることが水位変動スペクトル（図-4）から見 て取れる.

$\mathrm{x}_{\mathrm{c}}=12.2 \mathrm{~m}$ では，樹木群密度が粗から密に変化するため,

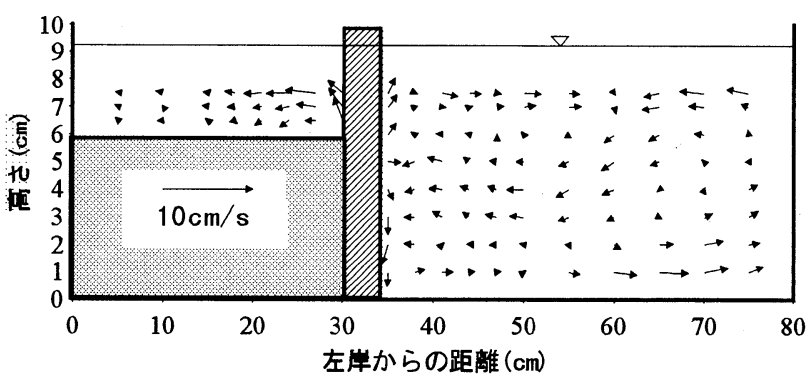

図-15 二次流ベクトル $\left(\mathrm{x}_{4}=12.0 \mathrm{~m}\right)$

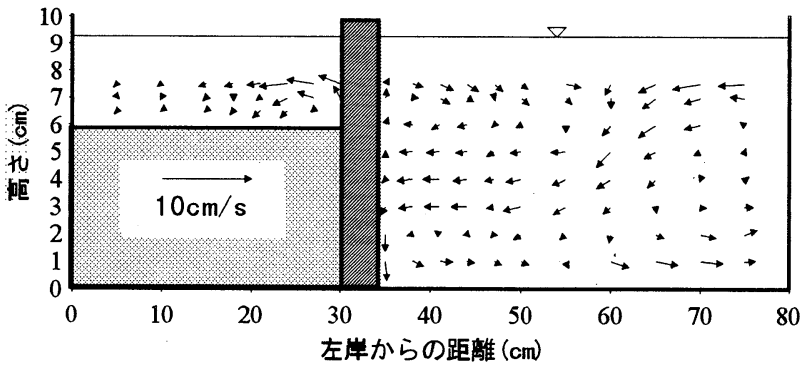

図-16 二次流ベクトル $\left(\mathrm{x}_{5}=12.8 \mathrm{~m}\right)$

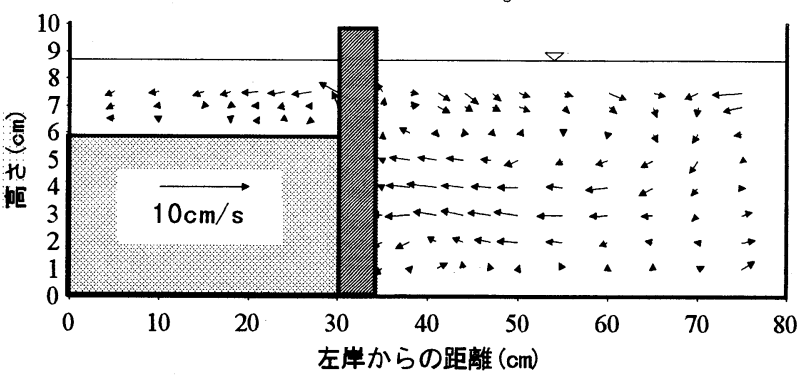

図-17 二次流ベクトル $\left(\mathrm{x}_{6}=16.0 \mathrm{~m}\right)$

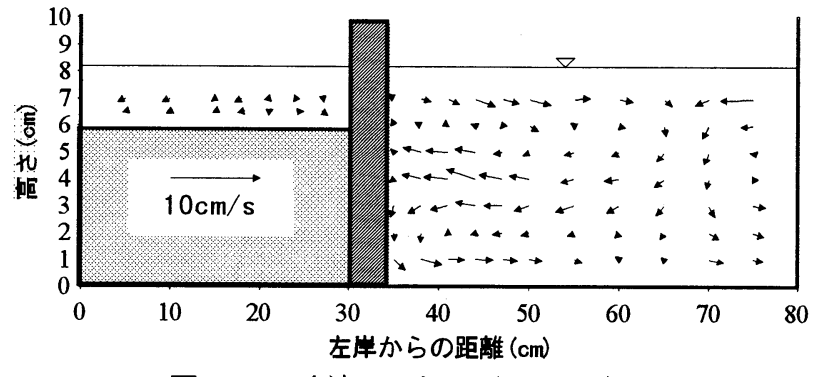

図-18 二次流ベクトル $\left(\mathrm{x}_{7}=20.0 \mathrm{~m}\right)$

それより下流では流れ場の遷移領域となる.

そU樹木群密度の変化断面ふら接が流下した $\mathrm{x}_{5}=12.8 \mathrm{~m}$ （図-16）では，低水路中央の下降流が若干強 く表れているものの, 粗な樹木群領域の二次流と似た特 徴を示している.

密な樹木群領域で $3.8 \mathrm{~m}$ 流下した $\mathrm{x}_{6}=16.0 \mathrm{~m}$ （図-17）で は, 樹木群周辺にあった水面付近の時計回りの二次流セ ルが拡大し，強く大きな二次流セルに発達している.こ のため, 粗な樹木群領域で存在していた低水路右岸側に あった反時計回りの二次流セルが水路右岸隅に押しつぶ された格好になっている。

密な樹木群領域で十分流下した $\mathrm{x}_{7}=20.0 \mathrm{~m}$ (図-18) で は，概ね $\mathrm{x}_{6}=16.0 \mathrm{~m}$ (図-17）と同様の二次流がみられ， 水位変動スペクトル（図-4）からも，流れ場は概ね変化 しきっているといえる.

以上より，樹木群密度が流下方向に粗から密に変化す 


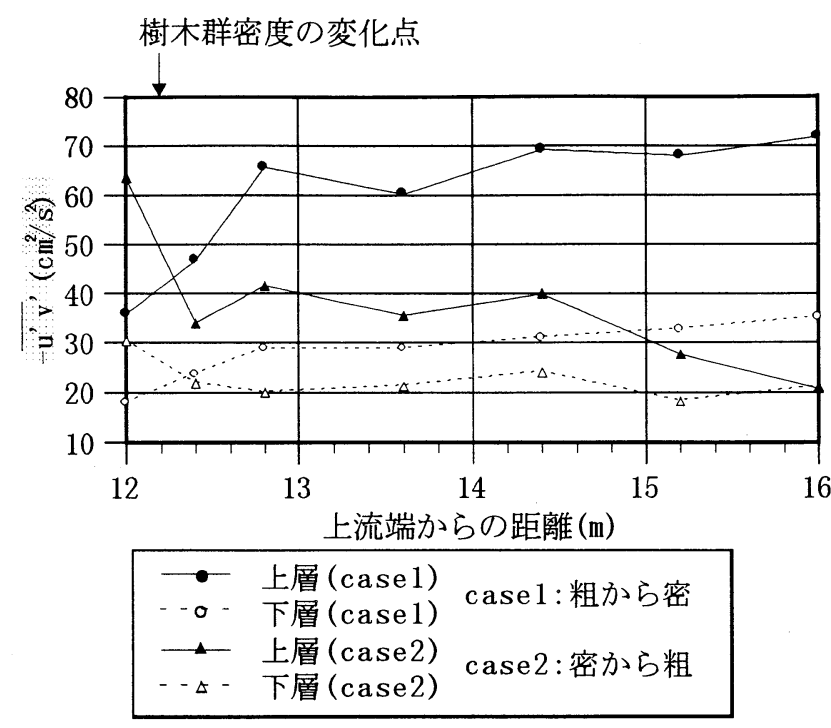

図-19 低水路側の樹木群境界面 $(\mathrm{y}=35.0 \mathrm{~cm}$ ) に作用する レイノルズ応力 $-\overline{u^{\prime} v^{\prime}}$ の縦断的な変化

ると，樹木群周辺の水面付近で現れる時計回りの二次流 セルが大きくなることが分かる．この二次流セルの発達 は, 水面付近でのレイノルズ応力が流下に伴って増大す ることにより，平均流速が流下方向に変化していく（図 -8）ことに関係している，つまり，この二次流セルは低 水路河岸に樹木群がある複断面流れの特徴的なものであ るといえる.

また, 樹木群密度の変化断面の前後 $\mathrm{x}_{6}=16.0 \mathrm{~m}$ と $\mathrm{x}_{7}=20.0 \mathrm{~m}$ （図-17，18）では二次流の大きな変化は見ら れない。

\section{（2）密から粗に変化する場合の変化過程 (case2)}

樹木群密度が流下方向に粗から密に変化する場合 (case1)，樹木群領域と主流域の流速差が増大するため, 平面渦は強くなる. それに対し, 樹木群密度が密から粗 に変化-9 万場合 (case2)，樹木群領域と主流域の流速差 は減少するため, 平面渦は弱くなる.

そこで両ケースの水平混合の強さを代表するものとし て，低水路側の樹木群境界面 ( $\mathrm{y}=35.0 \mathrm{~cm}$ ) に作用するレイ ノルズ応力 $\overline{u^{\prime} v^{\prime}}$ の縦断変化を図-19に示す.プロット した值は，高水敷高さで上層・下層に分けて鉛直平均し たレイノルズ応力 $\overline{u^{\prime} v^{\prime}}$ を示している.

図-19では，両ケースともに上層の $-\overline{u^{\prime} v^{\prime}}$ の縦断変化 は大きいが下層の変化は小さく, どちらのケースにおい ても水平混合の強さの変化は水面付近に顕著に表れると いえる. これは，低水路河岸の樹木群によって水面付近 での平面渦が卓越し，流れ場の 3 次元性が強まることに 起因している.

縦断変化の大きい上層の $-\overline{u^{\prime} v^{\prime}}$ を比較すると, case 1 では主に12.0〜12.8mの区間で変化しているのに対し， case2では12.0〜12.4mで集中して変化している. このよ うにcase $2 て ゙-\overline{u^{\prime} v^{\prime}}$ の変化距離が短い原因としては，粗 な樹木群は透過性が大きいため，流速差が解消されやす いことが挙げられる.

\section{4. 結論}

本研究では，低水路河岸に沿って連続的に樹木群が繁 茂している複断面河道において，樹木群密度が流下方向 に変化する水理模型実験を行い, 流れ場の 3 次元構造と その変化過程を明らかにした。

低水路河岸に樹木群が繁茂する複断面河道では，強い 大規模平面渦が発生することは従来から知られている. さらに本研究では，大規模平面渦が強まることにより， 特に高水敷高さより上層での水平混合が卓越するため, 水面付近での平均流が大きく減速されることを明らかに した. また，それに付随してレイノルズ応力ー $\overline{u^{\prime} w^{\prime}}$ によ る鉛直混合が活発な流れ場となることも明らかにした.

横断面内の流れとしては，樹木群周辺の水面付近におい て時計回りの二次流セルが発達することが特徴である.

また，樹木群境界に作用するレイノルズ応力ー $\overline{u^{\prime} v^{\prime}}$ は 樹木群密度の変化に素早く対応して変化するが，樹木群 密度が流下方向に増大する場合に比べ減少する場合のほ うが速やかに変化する。 また，樹木群境界に作用するレ イノルズ応力 $-\overline{u^{\prime} v^{\prime}}$ の作用が流れ場全体に波及し, 平均 流速場が変化するには遷移区間を要する.

以上のように，樹木群の透過性が縱断的に変化する複 断面河道流れは 3 次元的に複雑である. また，非線形性 の強い現象であり，様々な繁茂形態の樹木群を有する流 れの予測を行うためにも数值解析的な手段が有効である. 樹木群特性や水理条件の違いによる流れ場の遷移区間の 長さや抵抗の評価が可能な精度の高い3 次元数值モデル の開発が課題である.

\section{参考文献}

1) 福岡捷二, 藤田光一 : 洪水流に及ぼす河道内樹木群の水理的 影響, 土木研究所報告第 180 号 -1990.

2）福岡捷二, 渡辺明英, 津森貴行 : 樹木群を有する開水路にお ける平面せん断流の構造と解析，土木学会論文集No. 491 / II-27, pp. 41-50, 1994.

3) 辻本哲郎, 北村忠紀 : 側岸部に植生群落を有する開水路流れ の横断混合機構に関する実験的研究，土木学会論文集No. 491 /II-27, pp. 61-70, 1994.

4）畐永晃宏, 長尾正志, 劉建, 鈴木徹也 : 洪水流の抵抗と流れ 構造に及ぼす高水敷樹木群配置の影響, 水工学論文集, 第 39 巻, pp. 477-482, 1995.

5) 福剛捷二, 藤田光一, 新井田浩 : 樹木群を有する河道の洪水 位予測，土木学会論文集，No. 447／II-19，pp. 17-24， 1992

6) 灘岡和夫，八木宏 : SDS\&2DHモデルを用いた開水路水平せん 断乱流の数值シミュレーション，土木学会論文集No. 473／ II-24, pp. 35-44, 1993.

7）福岡捷二, 渡辺明英, 上坂恒雄, 津森貴行 : 低水路河岸に樹 木群のある河道の洪水流の構造一利根川新川通昭和56年8月 洪水一，土木学会論文集No. 509/II-30, pp. 97-88, 1995.2

8) 駒井克昭, 福岡捷二, 渡辺明英, 大本泰久 : 樹木群を有する 複断面開水路の流孔構造と解析，土木学会中国支部第50回研 究発表会発表概要集, pp. 217-218, 1998.

(1998. 9. 30受付) 